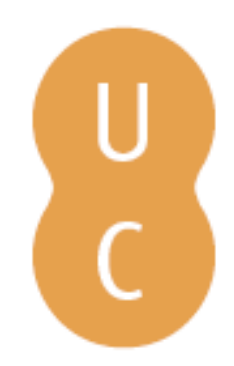

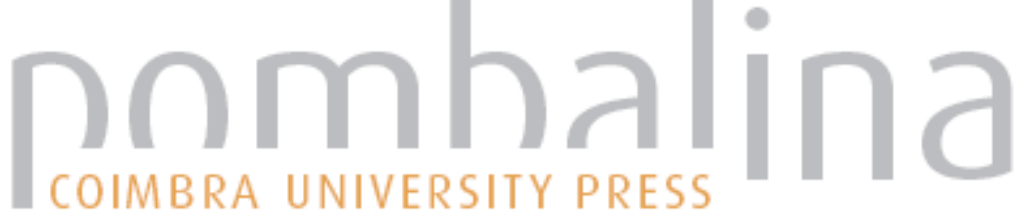

\section{One case of drowning after cyfluthrin ingestion}

\begin{tabular}{ll} 
Autor(es): & Monteiro, C.; Margalho, C.; Castanheira, F.; Mariano, A.; Nascimento, F.; \\
& Franco, J.; Corte-Real, F.; Vieira, D. N. \\
Publicado por: & $\begin{array}{l}\text { Imprensa da Universidade de Coimbra; International Academy of Legal } \\
\text { Medicine }\end{array}$ \\
$\begin{array}{ll}\text { URL } \\
\text { persistente: }\end{array}$ & URI:http://hdl.handle.net/10316.2/31872 \\
DOI: & DOI:http://dx.doi.org/10.14195/978-989-26-0173-1_63 \\
Accessed : & 26-Apr-2023 11:35:42 \\
\hline
\end{tabular}

A navegação consulta e descarregamento dos títulos inseridos nas Bibliotecas Digitais UC Digitalis, UC Pombalina e UC Impactum, pressupõem a aceitação plena e sem reservas dos Termos e Condições de Uso destas Bibliotecas Digitais, disponíveis em https://digitalis.uc.pt/pt-pt/termos.

Conforme exposto nos referidos Termos e Condições de Uso, o descarregamento de títulos de acesso restrito requer uma licença válida de autorização devendo o utilizador aceder ao(s) documento(s) a partir de um endereço de IP da instituição detentora da supramencionada licença.

Ao utilizador é apenas permitido o descarregamento para uso pessoal, pelo que o emprego do(s) título(s) descarregado(s) para outro fim, designadamente comercial, carece de autorização do respetivo autor ou editor da obra.

Na medida em que todas as obras da UC Digitalis se encontram protegidas pelo Código do Direito de Autor e Direitos Conexos e demais legislação aplicável, toda a cópia, parcial ou total, deste documento, nos casos em que é legalmente admitida, deverá conter ou fazer-se acompanhar por este aviso.

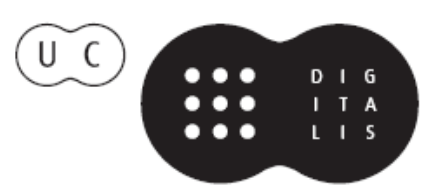




\section{Duarte Nuno Vieira Anthony Busuttil \\ Denis Cusack • Philip Beth}
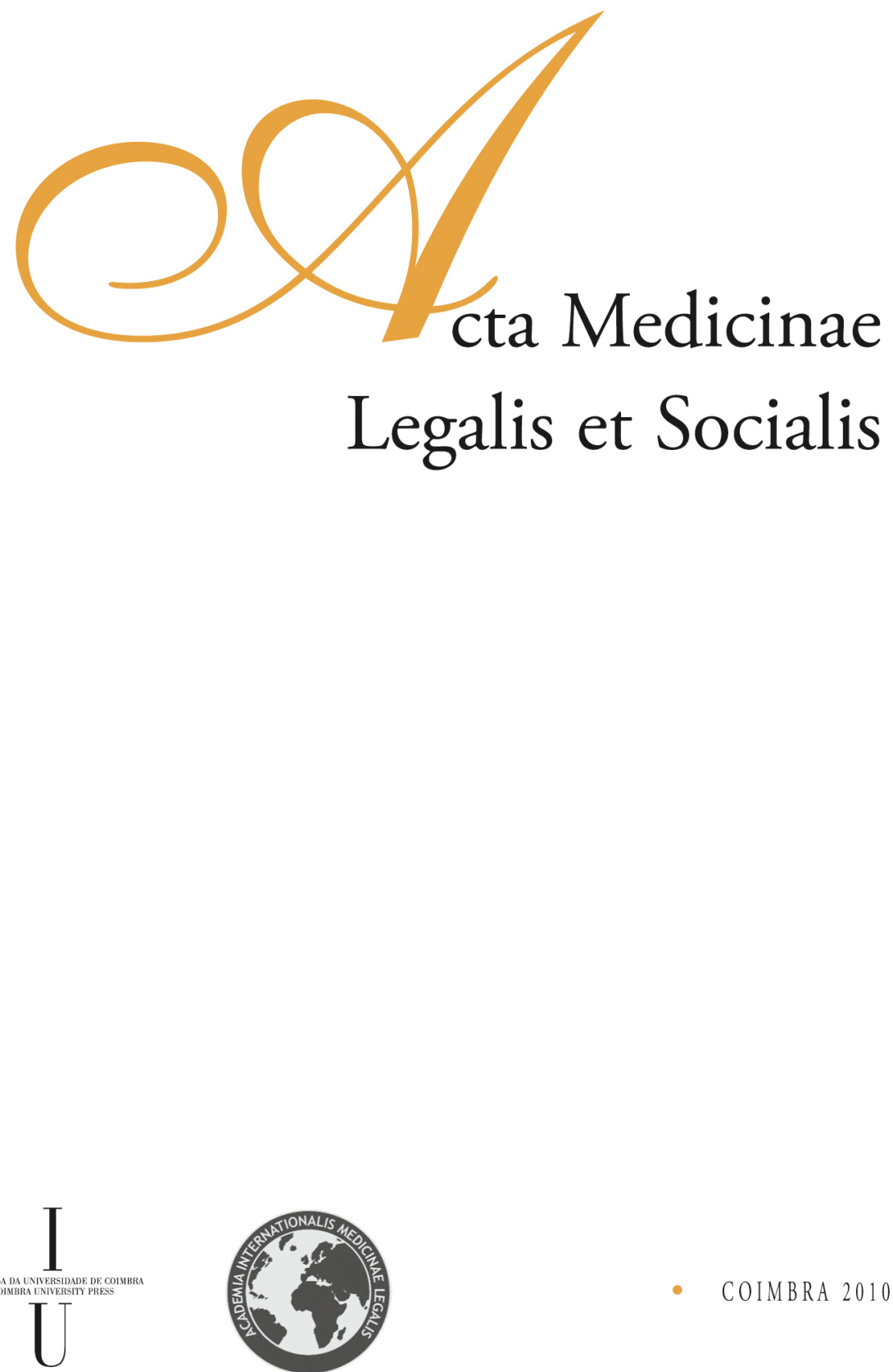


\author{
C. Monteiro ${ }^{1}$, C. Margalho ${ }^{1}$, F. Castanheira ${ }^{1}$, A. Mariano ${ }^{1}$, F. Nascimento ${ }^{1}$, \\ J. Franco ${ }^{1}$, F. Corte-Real ${ }^{1,2}$, D. N. Vieira ${ }^{1,2}$ \\ ${ }^{1}$ Centre Branch of the National Institute of Legal Medicine, Coimbra, Portugal \\ ${ }^{2}$ Faculty of Medicine, University of Coimbra, Portugal
}

\title{
ONE CASE OF DROWNING AFTER CYFLUTHRIN INGESTION
}

\begin{abstract}
This work reports a case, involving a 47-year-old Portuguese male found dead in a river. Near the victim clothes the authorities found two bottles containing a toxic product identified as cyfluthrin. Cyfluthrin is a synthetic pyrethroid insecticide that exerts its poison action through contact or ingestion.

Toxicological analyses were performed in blood, gastric content and in the bottles. Samples preparation was achieved using solid phase extraction and the extracts obtained were analysed by GC/MS.

Cyfluthrin was found in the gastric content and in the extract obtained after washing the bottles with a solvent.
\end{abstract}

Keywords: Cyfluthrin; suicide; blood; gastric content; GC/MS.

\section{Introduction}

Cyfluthrin is a pesticide belonging to the class of synthetic pyrethroids, which are a major class of pesticides, a group of chemicals that entered the marketplace in 1980 but, by 1982, accounted for more than 30 percent of worldwide insecticide usage $[1,2]$. These synthetics arise from a much older class of botanical insecticides, pyrethrum, a mixture of six insecticidal esters extracted from dried pyrethrum or chrysanthemum flowers. The ever-increasing demand for this product has far exceeded the limited world production, leading chemists to focus attention on the synthesis of new analogs, hopefully with better stability in light and air, better persistence, more selectivity in target species, and low mammalian toxicity $[2,3]$. In addition to extensive agricultural use, the synthetic pyrethroids are components of household sprays, flea preparations for pets, plant sprays for home and greenhouse use, and other applications. Natural pyrethrum consists of a mixture of six esters derived from two acids (chrysanthemic, pyrethric) and three alcohols (pyrethrolol, cinerolol, jasmolol), producing an effective contact and stomach poison mixture having both knockdown and lethality [2-5].

Pyrethroids' action as insecticide includes effects in sodium channel mechanism in the nervous system leading to disturbance of membrane polarization and abnormal discharges in neurons. Insects become paralyzed and die by dehydration and starvation. Pyrethroids can also act on isoforms of voltage-sensitive calcium channels, contributing to the discharge of neurotransmitters. This can lead to salivation and excitability in 
the central nervous system. Also chloride channels and possibly potassium channels can be involved [6,7]. Pyrethroids are divided in Type I, with T-syndrome (tremors), and Type II, with CS-syndrome (choreoathetosis with salivation). Cyfluthrin is a Type II pyrethroid, based on functional observatory battery data. In humans, pyrethroids' intoxication effects can include nauseas, loss of appetite, paresthesias, irritations of the skin and mucosa and headaches. Neurological effects can be seen after consuming foods with residues of cyfluthrin or exposed to applications [7-12]. Animal studies showed that symptoms can include beyond salivation, unusual hindlimb movements and body tremors. Cyfluthrin has a nearly full and quick absorption by ingestion or inhalation. Possibly because cyfluthrin does not accumulate in chronic exposures, the neurotoxicity is reversible and the effects are similar at maximum blood concentrations, the $\mathrm{WHO} / \mathrm{FAO}$ established a chronic acceptable daily intake based on an acute dosing study [12].

Cyfluthrin is a $(R S)$ - $\alpha$-cyano-4-fluoro-3-phenoxybenzyl-(1RS)-cis-trans-3-(2,2dichlorovinyl)-2,2-dimethyl-cyclopropane carboxylate (figure 1), being metabolized by esterases in cis- and trans-3-(2,2-dichlorovinyl)-2,2-dimethylcyclopropane carboxylic acid (DCCA) and 4-fluoro-3-phenoxybenzoic acid (FPBA), which are partially conjugated and eliminated by the kidneys [13].

\section{Case History}

A 47-year-old Portuguese male was found dead under water in a river. Authorities collected the victim clothes and two plastic bottles from the river bank, one containing a white pink liquid and the other identified as Baythroid® - cyfluthrin (figure 2). At the autopsy the samples collected were femoral blood and gastric content. Requested analyses included ethanol, drugs of abuse and pesticides.

\section{Material and Methods}

\section{Reagents and materials}

Ethion, used as internal standard (IS), was purchased from Sigma Aldrich (St. Louis, MO). Methanol and hexane were obtained from Merck (Darmstadt, Germany). Stock solution of internal standard was prepared in hexane at $1000 \mu \mathrm{g} / \mathrm{mL}$. Working solutions were prepared at $100 \mu \mathrm{g} / \mathrm{mL}$ by diluting stock solution with hexane. All solutions were kept protected from light and stored at $4^{\circ} \mathrm{C}$ until use. Other reagents used were all analytical grade.

Solid-phase extraction (SPE) Oasis ${ }^{\circledR}$ HLB $(60 \mathrm{mg})$ columns were obtained from Waters (Milford, MA). Deionized water was obtained using a Milli-Q system from Millipore (Molsheim, France). 


\section{Sample preparation}

To a $2 \mathrm{~mL}$ blood sample and $0,5 \mathrm{~mL}$ of stomach content it was added $5 \mu \mathrm{g}$ of the IS. Samples were diluted with 3 and $5 \mathrm{~mL}$ of deionized water, respectively, after being homogenized and centrifuged at $3000 \mathrm{rpm}$ for 10 minutes.

\section{Extraction procedure}

SPE columns were conditioned with $2 \mathrm{~mL}$ of methanol and $2 \mathrm{~mL}$ of deionized water. After samples were applied the columns were washed successively with $2 \mathrm{~mL}$ of $5 \%$ methanol:water $(\mathrm{v} / \mathrm{v})$, and then dried under vacuum for 30 minutes. The substances of interest were eluted with $2 \mathrm{~mL}$ of methanol and $2 \mathrm{~mL}$ of ethyl acetate. Subsequently, the eluate was evaporated to dryness under a gentle stream of N2 at $40^{\circ} \mathrm{C}$. The residue obtained was reconstituted in $100 \mu \mathrm{L}$ of methanol.

\section{Instrumentation and chromatographic conditions}

Instrumental analysis was performed using a Hewlett-Packard 6890 Series gas chromatograph coupled to a 5973 mass selective detector (Waldbronn, Germany). Chromatographic separation was achieved using a capillary column $(30 \mathrm{~m} \times 0.32 \mathrm{~mm}$ id $\times 0.25 \mu \mathrm{m}$ film thickness) with $5 \%$ phenylmethylsiloxane from Agilent. Carrier gas was helium with a flow rate of $1 \mathrm{~mL} / \mathrm{min}$. Volume injection was $1 \mu \mathrm{L}$ (split ratio 1:5). The oven was programmed to an initial temperature of $120^{\circ} \mathrm{C}$ held for 2 minutes, increased by $5{ }^{\circ} \mathrm{C} / \mathrm{min}$ to $240{ }^{\circ} \mathrm{C}$ and then $30^{\circ} \mathrm{C} / \mathrm{min}$ to a final temperature of 270 ${ }^{\circ} \mathrm{C}$, held for 20 minutes. The detector was operated in the EI mode $(70 \mathrm{eV})$, and the monitored ions were $\mathrm{m} / z$ 163, 206 and 226 for cyfluthrin and $m / z 231$ and 153 for IS.

\section{Results and Discussion}

Upon reception the samples were screened for ethanol and drugs of abuse in blood and pesticides in blood and in the gastric content. A positive result was obtained for cyfluthrin in the gastric content (figure 3).

Along with the samples, two bottles were received for analysis. The inside of the bottles was washed with methanol which was then analyzed by GC/MS giving also a positive result for cyfluthrin at both bottles (figure 4).

In the chromatograms (figures 3 and 4) we can observe the four diastereoisomers peaks obtained after analysis of the active substance as well as their mass spectrum.

As it can be observed from the analysis of chromatograms, the quality of the results (e.g. separation, capacity of detection) can be significantly improved with the use of a chromatographic column which is more appropriate to the characteristics of the substance involved. However, the variety of substances that can be detected in the routine of a forensic toxicology laboratory recommends the use of universal analytical columns, which obviously can not produce the best results with certain compounds in particular.

Due to the low mammalian toxicity, the mortal intoxication by cyfluthrin is not a common situation. Considering the casework of the Forensic Toxicology Service from 
the Centre Branch - National Institute of Legal Medicine (which includes the central area of Portugal), no cases were observed in the last 5 years (2005-2009). Nevertheless, the study of these substances has particular aspects to be considered by the pathologist.

The analysis of pyrethroids in different organs and tissue samples can be important to understand particular cases, due to its complex distribution. However, the toxicological analysis is limited usually to the samples collected by the pathologist which, sometimes, are not sufficient to a complete evaluation. Furthermore, the determination of different pyrethroids usually involves more complexity than organophosphats or carbamats, considering their characteristic cyclopropane rings which can cause the appearance of stereoisomers. Due to the possible binding of pyrethroids to erythrocytes and because no additional chromatographic peaks seems to appear when compared with serum analysis, the whole blood study represents a satisfactory way of pyrethroid testing [14].

The cyfluthrin acceptable daily intake of 0.02 to $0.04 \mathrm{mg} / \mathrm{kg}$ body weight per day is rapidly metabolized, by hydrolytic cleavage of the ester bond, followed by oxidation and mainly glucuronization. The cis-/trans-3-(2,2-dichlorovinyl)-2,2-dimethylcyclopropane carboxylic acid (DCCA) and 4-fluoro-3-phenoxybenzoic acid (FPBA) are almost totally excreted $(93 \%)$ within 24 hours after cyfluthrin inhalation exposure of $160 \mu \mathrm{g} / \mathrm{m} 3$, with peak excretion rate at $0.5-3 \mathrm{~h}$, depending on interindividual variation $[13,15]$. However, other studies observed an excretion of $35-50 \%$ of administered dose of type II pyrethroids in the first 5 days, with a urinary peak excretion at 24 hours. Due to the high excretion rate, urine samples from the first 3 hours after exposure can be useful, if creatinine correction is considered. The biomonitoring of cyfluthrin can be done directly in blood (or plasma) or by measuring the metabolites DCCA (common to other pyrethroids) and FPBA (specific to cyfluthrin) $[12,15,16]$.

\section{Conclusions}

Considering the pathologist report and the toxicological analysis, the results obtained highly suggest the occurrence of a suicide by drowning with the concomitant use of a toxic substance. As in other similar cases, the information collected by the authorities or experts on site has proved crucial to help the interpretation of the case.

\section{References}

[1] TOMLIN CDS, editor. The Pesticide Manual. 11th ed..BCPC, 1997.

[2] ECOBICHON DJ. Toxic effects of pesticides. In: Klaassen CD, editor. Casarett and Doull's Toxicology. New York, McGraw-Hill, 2001. Randall C.

[3] CASARETT Y DOULL'S. Toxicology, the Basic Science of Poison, 5th ed. C.D. Klaassen 1996.

[4] Ellenhorn's Medical Toxicology and Treatment of Human Poisoning, $2^{\text {th }}$ ed., 1997.

[5] Clarke's analysis of drugs and poisons, $3^{\text {rd }}$ ed. A.C. Moffat, M.D. Osselton and B. Widdop, Eds. Pharmaceutical Press, London, 2004, part one, pp 202-223 and part two, pp 866.

[6] HILDEBRAND ME, MCRORY JE, SNUTCH TP, STEA A. Mammalian voltage-gated calcium channels are potently blocked by the pyrethroid insecticide allethrin. J. Pharmacol. Exp. Ther., 308 (3), 805, 2004. 
[7] BRECKENRIDGE CB, HOLDEN L, STURGESS N, WEINER M, SHEETS L, SARGENT D, SODERLUND DM, CHOI JS, SYMINGTON S, CLARK JM, BURR S, RAY D, Evidence for a separate mechanism of toxicity for the Type I and the Type II pyrethroid insecticides. Neurotoxicology, 30S, S17-S31, 2009.

[8] HE F, SUN J, HAN K, WU Y, YAO P, Effects of pyrethroid insecticides on subjects engaged in packaging pyrethroids. Br. J. Ind. Med., 45, 548-551, 1988.

[9] HE F, WANG S, LIU L, CHEN S, ZHANG Z, SUN J, Clinical manifestation and diagnosis of acute pyrethroid poisoning. Arch. Toxicol., 63, 54-58, 1989.

[10] SODERLUND DM, CLARK JM, SHEETS LP, MULLIN LS, PICCIRILLO VJ, SARGENT D, STEVENS JT, WEINER ML, Mechanisms of pyrethroid neurotoxicity: implications for cumulative risk. Toxicology, 171, 3-59, 2002.

[11] CHEN S, ZHANG Z, HE F, YAO P, WU Y, An epidemiological study on occupational acute pyrethroid poisoning in cotton farmers. Br. J. Ind. Med., 48, 77-81, 1991.

[12] HAYS SM, AYLWARD LL, GAGNÉ M, KRISHNAN K, Derivation of Biomonitoring Equivalents for cyfluthrin, Regulatory Toxicology and Pharmacology, 55, 268-275, 2009.

[13] LENG C, LENG A, KUHN KH, LEWALTER J, PAULUHN J, Human dose-excretion studies with the pyrethroid insecticide cyfluthrin: urinary metabolite profile following inhalation, Xenobiotica, Vol. 27, N. 12, 1273-1283, 1997.

[14] RAMESH A, RAVI PE, Negative Ion Chemical Ionization-Gas Chromatographic-Mass Spectrometric Determination of Residues of Different Pyrethroid Insecticides in Whole Blood and Serum, Journal of Analytical Toxicology, Vol. 28, Nov/Dec, 2004.

[15] LENG G, GRIES W, Simultaneous determination of pyrethroid and pyrethrin metabolites in human urine by gas chromatography-high resolution mass spectrometry, Journal of Chromatography B, 814, 285-294, 2005.

[16] YOU J, WANG D, LYDY MJ, Determination of pyrethroid insecticides in sediment by gas chromatography-ion trap tandem mass spectrometry, Talanta, 81, 136-141, 2010.

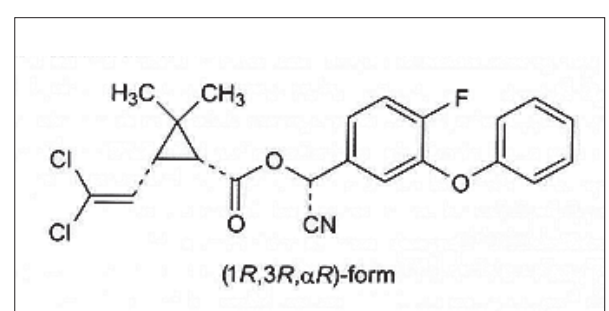

Figure 1 - Structure of cyfluthrin [5].

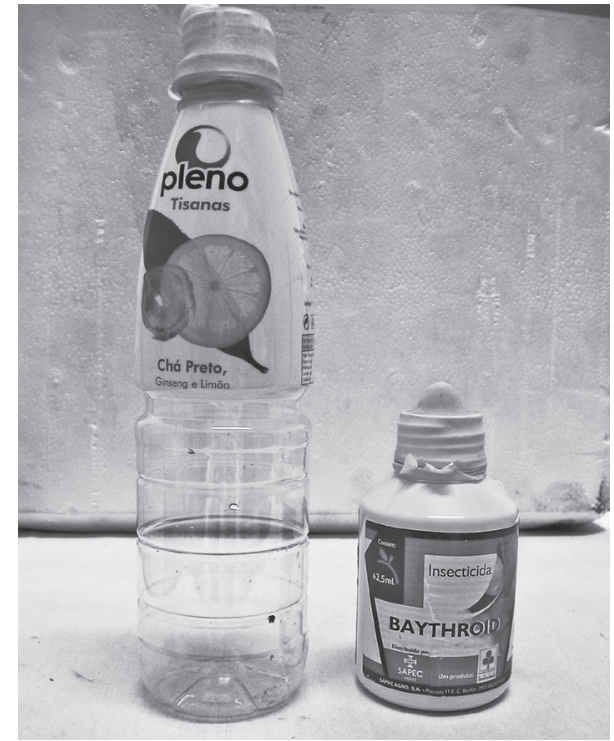

Figure 2 - Bottle with a white pink liquid; Bottle of Baythroid ${ }^{\circledR}$. 


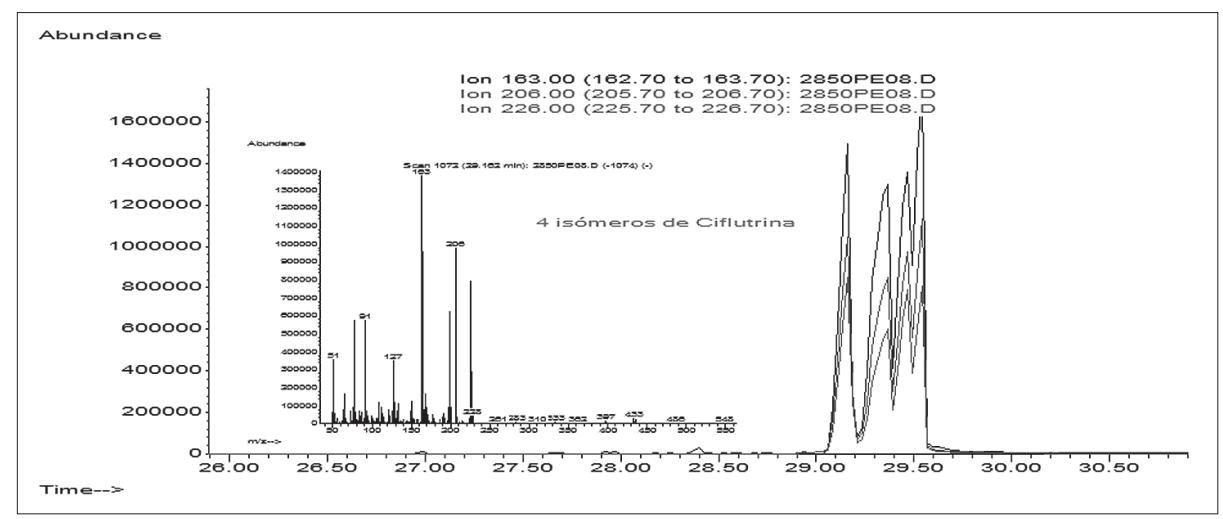

Figure 3 - Chromatogram obtained from the analysis of gastric content.

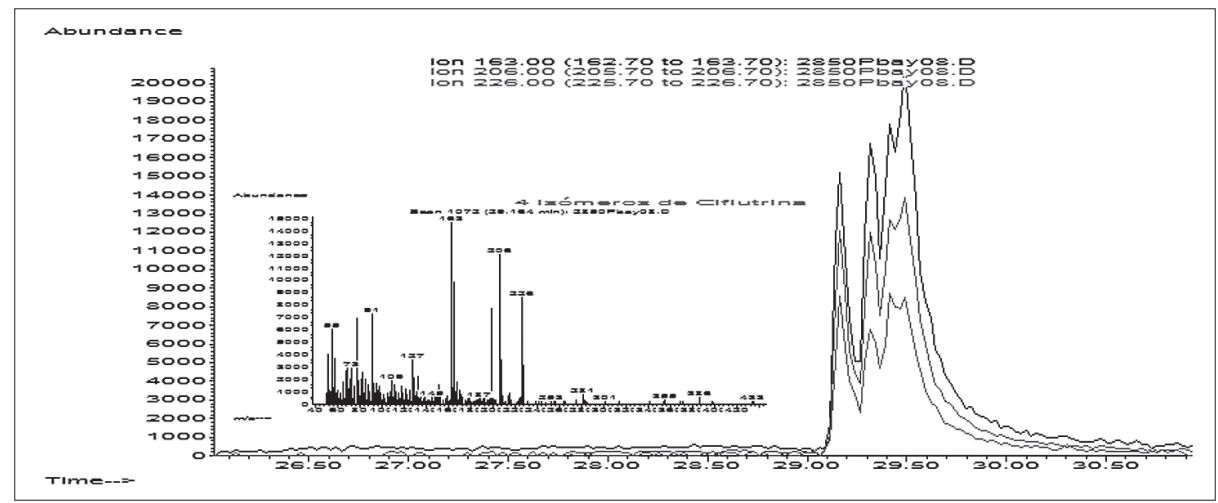

Figure 4 - Chromatogram obtained from the analysis of bottles content. 